International Journal of Health Sciences
Available online at www.Sciencescholar.us
Vol. 5 No. 3, December 2021, pages: $344-351$
e-ISSN: 2550-696X, p-ISSN: 2550-6978
https://doi.org/10.53730/ijhs.v5n3.1554

\title{
Midwives Preparation to Provide Delivery Services in Independent Midwife Practice During COVID-19 Pandemic
}

\author{
Siti Zakiah Zulfa a, Ova Emilia ${ }^{\text {b }}$, Asri Hidayat c \\ Manuscript submitted: 27 April 2021, Manuscript revised: 18 August 2021, Accepted for publication: 29 September 2021
}

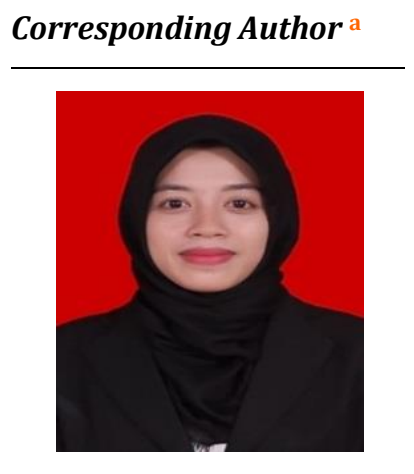

\section{Keywords}

COVID-19 pandemic; health care facilities; health services; midwife practice; midwives; vaccinations;

\begin{abstract}
The COVID-19 pandemic has had a tremendous impact on the world of health, including delivery services at the independent midwife practice. Midwives must change their service system and follow maternity service procedures that the central government has set. The purpose of the study was to explore in-depth the preparation of midwives in providing delivery services at independent midwife practice during the COVID-19 pandemic. This study uses descriptive qualitative research through a phenomenological approach involving seven informants. Data were collected utilizing one-on-one in-depth online interviews using a semi-structured interview guide. Data analysis was done manually using thematic analysis. Data analysis shows that midwives are prepared to provide delivery services at independent midwife practice during the COVID-19 pandemic by modifying infrastructure, providing Personal Protective Equipment (PPE), providing information about COVID-19, disseminating delivery service guidelines, and providing support, vaccinations, rapid screening tests for midwives.
\end{abstract} (https://creativecommons.org/licenses/by-nc-nd/4.0/).

\section{Contents}

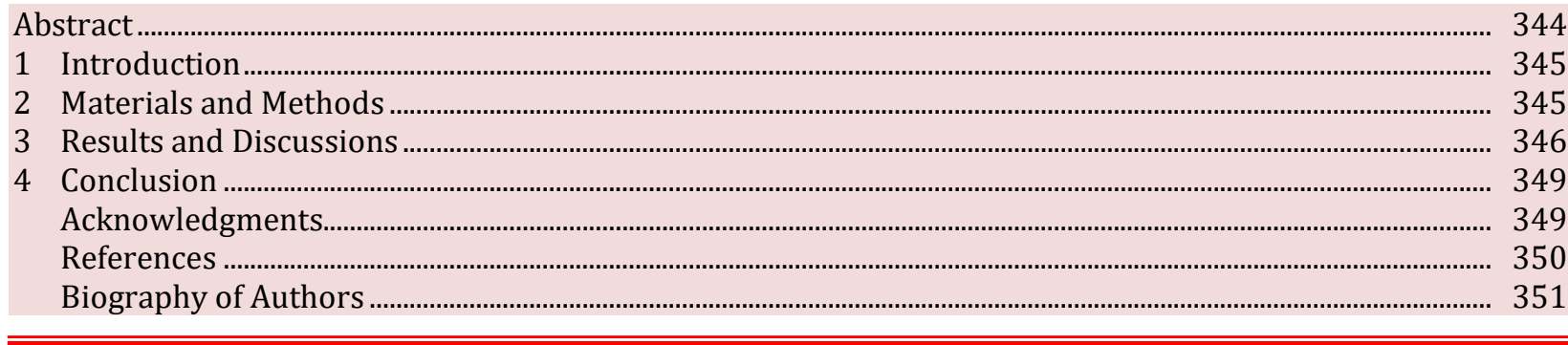

\footnotetext{
a Universitas Aisyiyah, Yogyakarta, Indonesia

b Universitas Gadjah Mada, Yogyakarta, Indonesia

c Universitas Aisyiyah, Yogyakarta, Indonesia
} 


\section{Introduction}

Coronavirus Disease 2019 or known as the COVID-19 virus, first appeared in China in December 2019. Currently, COVID-19 has spread throughout the world. The spread of the COVID-19 virus has reached Macau, Hong Kong, other Asian countries, and even Europe (Li et al., 2020). Based on data from the Ministry of Health of the Republic of Indonesia, currently, there are 215 countries affected by the COVID-19 virus and as many as 179 countries experiencing local transmission (Kementerian Kesehatan Republik Indonesia, 2020a). On March 11, 2020, the World Health Organization (WHO) declared the COVID-19 virus a global pandemic (World Health Organization, 2020a).

The emergence of the COVID-19 virus has had a tremendous impact on all aspects of life, especially in the world of health. Based on a survey from the WHO regarding the impact of the COVID-19 virus on the health system, it was reported that around $90 \%$ of countries experienced disruptions in health services (Wang et al., 2007). Low- and middle-income countries experience the most significant difficulty. Most countries report that many routine and elective services are suspended, while critical care is at high risk of disruption, especially in low-income countries during the pandemic (World Health Organization, 2020).

On the other hand, when many health services experienced disruption during the pandemic (Katon, 2003), the birth rate increased in Indonesia. Data from the Central Board of the Indonesian Midwives Association states that deliveries from January to April 2020 have increased. The number of deliveries in January was 25,268 cases, February 25,392 cases, March 26,094 cases, and April 27,070 cases (Ikatan Bidan Indonesia, 2020). When viewed from the side of the surrogate and birthing place, most deliveries were assisted by midwives by $62.7 \%$, and most places of delivery were carried out in independent midwife practice by $29.6 \%$ (Kementerian Kesehatan Republik Indonesia, 2019).

During the COVID-19 pandemic, health care facilities including independent midwife practice, must modify their service system and follow delivery service procedures that the central government has set to prevent the spread of the COVID-19 virus. Regarding this regulation, the Indonesian government, through the Indonesian Ministry of Health has made a policy by issuing service guidelines for maternity mothers in the COVID-19 pandemic era (Kementerian Kesehatan Republik Indonesia, 2020b). Following up on these regulations, various special preparations including modification of infrastructure were carried out by health service facilities, including independent midwife practice to adjust to the conditions of the COVID-19 pandemic.

Semaan et al. (2020), mentioned that one of the adaptations made by several health care facilities in the face of the COVID-19 pandemic was implementing social distancing in the outpatient waiting room. A preliminary study of independent midwife practice owners in Sleman Regency explained that preparation for the COVID-19 pandemic at independent midwife practice was by modifying infrastructure, such as installing barriers between midwives and patients in the registration room to prevent aerosols (Hall et al., 2012). In its implementation in the field, each independent midwife practice made various preparations to prevent the transmission of the COVID-19 virus in their respective health care facilities. This study aims to explore indepth the preparation of midwives to provide delivery services at independent midwife practice during the COVID-19 pandemic (Fahy \& Parratt, 2006; Goemaes et al., 2020).

\section{Materials and Methods}

This study uses a qualitative descriptive study with a phenomenological approach. The selection of this study was intended to explore and understand the meaning related to the preparation of midwives to provide delivery services at independent midwife practice during the COVID-19 pandemic by describing this phenomenon in the form of words and natural language. This research was conducted on three independent midwife practice pomegranate midwives in Sleman Regency. The informants in this study involved one head of the Branch Management of Indonesian Midwives Association in Sleman Regency and three independent midwife practice owners as key informants and three implementing midwives as critical informants who met the inclusion criteria (Arrish et al., 2014; Widana et al., 2021). Determination of the number of informants based on the adequacy of data and the principle of data saturation using purposive sampling and convenience sampling techniques for taking informants in this study.

Zulfa, S. Z., Emilia, O., \& Hidayat, A. (2021). Midwives preparation to provide delivery services in independent midwife practice during COVID-19 pandemic. International Journal of Health Sciences, 5(3), 344-351.

https://doi.org/10.53730/ijhs.v5n3.1554 
Primary data was collected by conducting one on one in-depth online interviews using synchronous interview techniques through the Zoom cloud meetings application and voice notes on the WhatsApp application. The interviews were conducted based on a semi-structured interview guide that had passed the constructed test with the help of expert judgment, and pilot interviews were conducted with two informants. The secondary data collection of this study used a research activity logbook, field notes, observation checklist sheets, and documentary evidence (pictures). Data analysis was done manually using thematic analysis. This research was conducted after receiving a research ethic eligibility letter from the Health Research Ethics Committee of the University of 'Aisyiyah Yogyakarta with No.1834/KEP-UNISA/VII/2021.

\section{Results and Discussions}

\section{Modification of infrastructure}

Face the COVID-19 pandemic; many special preparations were made by midwives at independent midwife practices so that delivery services could still be provided. These preparations include modifying infrastructure by installing barriers (made of clear plastic) between midwives and patients in several rooms such as registration rooms, medicine rooms, and examination rooms to prevent aerosols.

"In the delivery room, there is a delivery chamber, in the registration room there is also a kind of curtain made of transparent plastic so that it does not come into direct contact with the patient's droplets" [Bd.1].

Midwives also provide a delivery chamber in the delivery room, but one independent midwife practice does not install a delivery chamber because they understand that the provision of the delivery chamber in the independent midwife practice is not a requirement but only a recommendation.

"There is no delivery chamber because it is not an obligation for procurement at independent midwife practice. As far as I know, it is not mandatory and only a recommendation" [Pm.2].

This is contrary to the Indonesian Ministry of Health, which states that delivery services at First Level Health Facilities during the COVID-19 pandemic use a delivery chamber (Kementerian Kesehatan Republik Indonesia, 2020 b). In addition, the midwife at independent midwife practice also installs a sink at the entrance, provides hand sanitizer in every place the patient passes, applies the principle of social distancing for the waiting room by placing a cross sign or leaving a distance of 1 meter between chairs and providing a UV-C ray sterilizer for the room.

\footnotetext{
"Preparing a sink in front of the independent midwife practice door, providing hand sanitizer in every place that is seen and passed by the patient" [Pm.2]. "I gave a distance of 1 meter for chairs in the waiting room during the pandemic, I also already have a UV-C sterilizer for the room" [Pm.3].
}

In line with research conducted by Semaan et al. (2020), describes one of the adaptations made by several health care facilities in the face of the COVID-19 pandemic by implementing social distancing in outpatient waiting rooms. The results of other studies explain that preventing the transmission of nosocomial infections in hospitals can be done using UV-C rays. Light waves from UV-C rays can kill microorganisms and inactivate viruses so that they can be implemented in health care facilities during the COVID-19 pandemic (Ramos et al., 2020).

\section{Providing Personal Protective Equipment (PPE)}

Providing delivery services at independent midwife practices during the pandemic must pay attention to the rules for implementing health protocols to prevent COVID-19 transmission in health care facilities. One of the efforts made by midwives is to provide standard level 2 and level 3 of PPE such as surgical masks, N-95 masks/equivalent masks, rubber hand scoops, rubber surgical hand scoops, gowns, hazmat or coveralls, head cups, goggles, face shields, rubber shoes, and shoe protection. 
"We provide PPE level 2 to PPE level 3" [Pm.3]. "Independent midwife practice provides complete PPE such as boots, KN-94/N-95 masks, face shields, hazmats, shoe protectors, and hand scoops. Then there are also gowns and head cups" [Bd.3].

In addition, midwives in independent midwife practice also receive support from professional organizations (Branch Management of Indonesian Midwives Association in Sleman Regency) through social service activities and PPE assistance to their members (independent midwives practice in Sleman). The assistance provided was in masks (surgical masks and cloth masks), face shields, hand scoops, aprons, hazmats, hand soap, and hand sanitizer.

"Indonesian Midwives Association provides PPE assistance for midwives, such as masks, head cups, hazmats, shoes to hand scoops, and others. We also provide handsoap assistance to midwives" [Pc.1].

In line with research conducted by Liu Qian et al. (2020), health workers who worked during the COVID-19 pandemic received various supports, including from their workplace, co-workers, family, friends, and the community. The hospital provides solid logistical support, such as providing PPE equipment and others.

\section{Providing information about COVID-19 and socializing delivery service guidelines to implementing midwives}

Midwives are prepared to face the pandemic by providing information about COVID-19 and socializing delivery service guidelines to implementing midwives at independent midwife practice through offline and online activities (Ningsih et al., 2021). Offline activities include meeting agendas with the Sleman District Health Office, discussing the manual referral system during the COVID-19 pandemic, and socializing the latest 2020 Maternal Child Health book revision. The implementation of online activities is carried out with professional organizations (Indonesian Midwives Association), District Health Offices Sleman, and regional health centers through webinar agendas, seminars, online meetings or meetings via zoom, online meetings with hospitals, and information through circulars.

"Socialization of the guidelines through offline and online meetings. If the midwife does not participate in the activity, it will be distributed through the WhatsApp group" [Pm.1].

In addition, information about COVID-19 and socialization of delivery service guidelines were obtained by midwives through WhatsApp groups such as the independent midwife practice internal group, independent midwives practice in Sleman group, Indonesian Midwives Association group, Branch Management of Indonesian Midwives Association group, pomegranate midwife group, hospital branch group, and others. Implementing midwives independently also seek information about COVID-19 through social media and share information with fellow midwives.

"Information about COVID-19 from social media, WhatsApp group applications such as the independent midwife practice Group, Branch Management of Indonesian Midwives Association in Sleman Regency group, pomegranate midwife group, and others" [Pm.3]. "We can get the information through social media, it can also be from independent midwife practice WhatsApp groups, many from social media and co-workers" [Bd.1].

In line with research conducted by Semaan et al. (2020), as many as $92 \%$ of health workers seek information about COVID-19 independently, and as many as $90 \%$ of health workers receive informal guidance on the care of pregnant women and newborns during the COVID-19 pandemic from co-workers. Although there have been many sources of information obtained by implementing midwives related to COVID-19, the facts on the ground have found that no midwives have received special training related to COVID-19 or delivery services during the COVID-19 pandemic.

"There is no training related to COVID-19 for midwives who work in independent midwife practice" [Bd.1].

Zulfa, S. Z., Emilia, O., \& Hidayat, A. (2021). Midwives preparation to provide delivery services in independent midwife practice during COVID-19 pandemic. International Journal of Health Sciences, 5(3), 344-351. https://doi.org/10.53730/ijhs.v5n3.1554 
Research conducted by Semaan et al. (2020), stated that only a third of 714 health workers received training or hands-on training on the response to COVID-19. Meanwhile, Chang et al. (2020), stated that education for health workers must be carried out and vigilance must be increased for the preparedness of health care facilities to face the COVID-19 pandemic.

\section{Support for midwives}

Other preparations made by midwives at independent midwife practice to deal with the COVID-19 pandemic are to maintain stamina or endurance, such as taking vitamin supplements, eating nutritious food, and consuming honey that they provide independently (Carchi et al., 2021). Midwives also maintain sleep patterns with adequate rest, adhere to health protocols, and maintain personal hygiene such as bathing and changing clothes after finishing guarding or returning from independent midwife practice.

"I maintain my immune system by taking supplements, eating nutritious foods, honey, or certain vitamins. I also pay more attention to rest periods and adhere to health protocols, take a shower and change clothes after coming home from duty" [Bd.1].

In addition, midwives also receive support from their workplaces, such as vitamin C, honey, and medicines (if needed).

"We were given food every day and vitamins from independent midwife practice" [Bd.3]. "We prepare vitamins, honey and medicine for midwives at independent midwife practice" [Pm.1].

In line with research conducted by Liu Qian et al. (2020), which states that hospitals in Hubei province, China support health workers by providing PPE equipment, accommodation, transportation, food, medicines, and subsidies. Although there has been much preparation and support for midwives at independent midwife practice, only one independent midwife practice provides additional wages to implementing midwives during the COVID-19 pandemic, and no independent midwife practice provides health insurance for midwives.

"Independent midwife practice provides an additional salary for employees during the pandemic" [Pm.3].

"There is no insurance or health insurance for employees" [Bd.1].

This is a concern, considering that an implementing midwife is a group that is vulnerable to being infected with the COVID-19 virus. In addition, compensation is also needed to support the performance of midwives in providing health services during the pandemic. Spoorthy et al. (2020), explained in their research that health workers continued to work during the COVID-19 pandemic because of additional financial compensation.

\section{Vaccination for midwives}

Vaccination for midwives is also carried out as a form of preparedness to face the pandemic and is one of the efforts to prevent the spread of the COVID-19 virus (Loulergue et al., 2009; Steyer et al., 2004). independent midwife practice applies vaccination rules for all implementing midwives. The vaccination activity is a program from the Sleman District Health Office, which was carried out on January 28, 2021, and was the first vaccination activity carried out in Sleman Regency specifically for all health workers who provide services to the community in Sleman Regency.

"We have all vaccinated Sinovac" [Bd.2]. "Vaccination for midwives in Sleman Regency has reached more than $82 \%$ at present" [Pc.1].

Vaccination for midwives at independent midwife practice is the right thing to do, considering that one way to suppress the transmission of COVID-19 can be done with a vaccination program. Wang et al. (2020), explained that in their research, there is currently no specific antiviral treatment for COVID-19, and immunization is one of the most successful and cost-effective health interventions to prevent infectious diseases, so vaccines against COVID-19 are considered very important for preventing and control the spread of the COVID-19 virus. 
Screening rapid test for midwives

Midwives at independent midwife practices also get rapid test facilities from their respective workplaces as a form of preparation for the COVID-19 pandemic. Unfortunately, this rapid test is not carried out routinely but only when indications are needed. For example, a rapid test is carried out when the midwife is in close contact with a COVID-19 patient.

"So far, there are no routine or periodic rapid tests, there is no routine screening, so it is based on complaints only and is conditional. Rapid tests are carried out if necessary" [Bd.2].

Routine rapid test checks for midwives need to be carried out, considering that many cases of people infected with COVID-19 do not have symptoms or are commonly called people without symptoms. Meanwhile, midwives at independent midwife practices provide services to the community and are included in groups who have a high risk of being infected with COVID-19. Midwives may transmit or contract the COVID-19 virus while providing services. Research conducted by Paradiso et al. (2021), regarding COVID-19 screening and people without symptoms monitoring of health workers with rapid serological tests stated no published data regarding the incidence of people without symptoms health workers infected with COVID-19. This study involved 606 health workers working in cancer institutions, and their blood samples were taken for rapid serological tests on days 0 to 14 . The results showed that overall, nine $(1.5 \%)$ health workers had reactive rapid test results, and one of them was confirmed positive after PCR.

\section{Conclusion}

Careful preparations need to be made by midwives while providing delivery services at independent midwife practice during the COVID-19 pandemic, considering the risk of being infected to death is very vulnerable to occur in midwives. Training related to COVID-19 and delivery services during the pandemic, financial support, health insurance, and routine rapid test screening for midwives must be carried out and become a particular concern for all independent midwife practice.

\section{Acknowledgments}

We want to thank the family, especially our parents, for their never-ending support and encouragement. In addition, we would like to thank the informants involved in this research for giving us the time and opportunity to share their experiences.

Zulfa, S. Z., Emilia, O., \& Hidayat, A. (2021). Midwives preparation to provide delivery services in independent midwife practice during COVID-19 pandemic. International Journal of Health Sciences, 5(3), 344-351. https://doi.org/10.53730/ijhs.v5n3.1554 


\section{References}

Arrish, J., Yeatman, H., \& Williamson, M. (2014). Midwives and nutrition education during pregnancy: A literature review. Women and Birth, 27(1), 2-8. https://doi.org/10.1016/j.wombi.2013.02.003

Carchi, J. A. Y. ., Catagua, T. C. M. ., Rivera, D. G. B. ., Mera, V. B. ., \& Rosario, M. del . (2021). From beginner to expert, experience of the rotating nursing intern in pre-professional practice. International Journal of Health Sciences, 5(2), 111-117.

Chang, Y. T., Lin, C. Y., Tsai, M. J., Hung, C. T., Hsu, C. W., Lu, P. L., \& Hou, M. F. (2020). Infection control measures of a Taiwanese hospital to confront the COVID-19 pandemic. The Kaohsiung journal of medical sciences, 36(5), 296-304.

Fahy, K. M., \& Parratt, J. A. (2006). Birth territory: a theory for midwifery practice. Women and birth, 19(2), 4550. https://doi.org/10.1016/j.wombi.2006.05.001

Goemaes, R., Beeckman, D., Verhaeghe, S., \& Van Hecke, A. (2020). Sustaining the quality of midwifery practice in Belgium: challenges and opportunities for advanced midwife practitioners. Midwifery, 89, 102792. https://doi.org/10.1016/j.midw.2020.102792

Hall, H. G., McKenna, L. G., \& Griffiths, D. L. (2012). Midwives' support for complementary and alternative medicine: a literature review. Women and Birth, 25(1), 4-12. https://doi.org/10.1016/j.wombi.2010.12.005

Ikatan Bidan Indonesia. (2020). Situasi Pelayanan Kebidanan pada Masa Pandemi COVID-19.1-32.

Katon, W. J. (2003). Clinical and health services relationships between major depression, depressive symptoms, and general medical illness. Biological psychiatry, 54(3), 216-226. https://doi.org/10.1016/S0006-3223(03)00273-7

Kementerian Kesehatan Republik Indonesia. (2019). Laporan Hasil Riset Kesehatan Dasar (Riskesdas) Indonesia tahun 2018. In Riset Kesehatan Dasar Kementerin Kesehatan RI 2019.

Kementerian Kesehatan Republik Indonesia. (2020a, August 22). Home» Info Infeksi Emerging Kementerian Kesehatan RI. Kementerian Kesehatan Republik Indonesia. https://infeksiemerging.kemkes.go.id/

Kementerian Kesehatan Republik Indonesia. (2020b). Pedoman Pelayanan Bagi Ibu Hamil, Bersalin, Nifas, dan Bayi Baru Lahir. Kementerian Kesehatan Republik Indonesia. https://www.ibi.or.id/media/Materi Webinar IBI - USAID Jalin Covid19/Kementerian Kesehatan_COVID_19_Pedoman.pdf

Li, W., Yang, Y., Liu, Z. H., Zhao, Y. J., Zhang, Q., Zhang, L., ... \& Xiang, Y. T. (2020). Progression of mental health services during the COVID-19 outbreak in China. International journal of biological sciences, 16(10), 1732.

Liu, Q., Luo, D., Haase, J. E., Guo, Q., Wang, X. Q., Liu, S., ... \& Yang, B. X. (2020). The experiences of health-care providers during the COVID-19 crisis in China: a qualitative study. The Lancet Global Health, 8(6), e790e798. https://doi.org/10.1016/S2214-109X(20)30204-7

Loulergue, P., Moulin, F., Vidal-Trecan, G., Absi, Z., Demontpion, C., Menager, C., ... \& Launay, O. (2009). Knowledge, attitudes and vaccination coverage of healthcare workers regarding occupational vaccinations. Vaccine, 27(31), 4240-4243. https://doi.org/10.1016/j.vaccine.2009.03.039

Ningsih, S., Ismail, D., \& Indriani, I. (2021). Study protocol: relationship between parenting patterns and diet with nutritional status of toddlers during COVID-19 pandemic. International Journal of Health Sciences, 5(2), 128-134.

Paradiso, A. V., De Summa, S., Silvestris, N., Tommasi, S., Tufaro, A., Larocca, A. M. V., ... \& De Palma, G. (2021). Prospective Observational COVID-19 Screening and Monitoring of Asymptomatic Cancer Center HealthCare Workers with a Rapid Serological Test. Diagnostics, 11(6), 975.

Ramos, C. C. R., Roque, J. L. A., Sarmiento, D. B., Suarez, L. E. G., Sunio, J. T. P., Tabungar, K. I. B., ... \& Hilario, A. L. (2020). Use of ultraviolet-C in environmental sterilization in hospitals: A systematic review on efficacy and safety. International Journal of Health Sciences, 14(6), 52.

Semaan, A., Audet, C., Huysmans, E., Afolabi, B., Assarag, B., Banke-Thomas, A., ... \& Benova, L. (2020). Voices from the frontline: findings from a thematic analysis of a rapid online global survey of maternal and newborn health professionals facing the COVID-19 pandemic. BMJ Global Health, 5(6), e002967.

Spoorthy, M. S., Pratapa, S. K., \& Mahant, S. (2020). Mental health problems faced by healthcare workers due to the COVID-19 pandemic-A review. Asian journal of psychiatry, 51, 102119. https://doi.org/10.1016/j.ajp.2020.102119

Steyer, T. E., Ragucci, K. R., Pearson, W. S., \& Mainous III, A. G. (2004). The role of pharmacists in the delivery of influenza vaccinations. Vaccine, 22(8), 1001-1006. https://doi.org/10.1016/j.vaccine.2003.08.045 
Wang, J., Jing, R., Lai, X., Zhang, H., Lyu, Y., Knoll, M. D., \& Fang, H. (2020). Acceptance of COVID-19 Vaccination during the COVID-19 Pandemic in China. Vaccines, 8(3), 482.

Widana, I.K., Sumetri, N.W., Sutapa, I.K., Suryasa, W. (2021). Anthropometric measures for better cardiovascular and musculoskeletal health. Computer Applications in Engineering Education, 29(3), 550561. https://doi.org/10.1002/cae.22202

Wang, P. S., Aguilar-Gaxiola, S., Alonso, J., Angermeyer, M. C., Borges, G., Bromet, E. J., ... \& Wells, J. E. (2007). Use of mental health services for anxiety, mood, and substance disorders in 17 countries in the WHO world mental health surveys. The Lancet, 370(9590), 841-850. https://doi.org/10.1016/S0140-6736(07)614147

World Health Organization. (2020a, March 11). WHO Director-General's opening remarks at the media briefing on COVID-19 - 11 March 2020. World Health Organization.

World Health Organization. (2020b, August 31). In WHO global pulse survey, $90 \%$ of countries report disruptions to essential health services since COVID-19 pandemic. World Health Organization.

\section{Biography of Authors}

\begin{tabular}{|l||}
\hline Siti Zakiah Zulfa, S. SiT. \\
Completed D-III Midwifery education in 2014 at Stikes 'Aisyiyah Yogyakarta, \\
Indonesia, and completed D-IV Midwifery education in 2016 at University of \\
'Aisyiyah Yogyakarta, Indonesia. She is currently pursuing a Masters's degree in \\
Midwifery at the University of 'Aisyiyah Yogyakarta \\
Email: zakiahzlf@gmal.com
\end{tabular} \mid \begin{tabular}{l|l|}
\hline Prof. dr. Ova Emilia, M.Med.Ed., Sp.0G(K)., Ph.D. \\
She completed medical education at Gajah Mada University in Indonesia, then \\
completed her Master of Medical Education at Dundee University, UK. She then \\
completed her specialist education in Obstetrics and Gynecology (Sp. OG) at \\
Gadjah Mada University Yogyakarta, Indonesia, and completed her Doctoral \\
(Ph.D.) education in Clinical Education at the University of New South Wales, \\
Sydney, Australia. Then completed her Consulting Specialist or SpOG(K) education \\
at Gadjah Mada University Yogyakarta, Indonesia, and currently serves as the first \\
Professor of Medical education in Indonesia and works as a lecturer at the Faculty \\
of Medicine, Public Health and Nursing at Gadjah Mada University Yogyakarta, \\
Indonesia. \\
Email: ovaemilia@gmail.com
\end{tabular}

Zulfa, S. Z., Emilia, O., \& Hidayat, A. (2021). Midwives preparation to provide delivery services in independent midwife practice during COVID-19 pandemic. International Journal of Health Sciences, 5(3), 344-351. https://doi.org/10.53730/ijhs.v5n3.1554 